FORUM

Putting neo-liberalism in its place(s) 


\title{
Living with/in and without neo-liberalism
}

\author{
John Clarke
}

\begin{abstract}
This article explores some concerns about the concept of neo-liberalism, suggesting that it has been stretched too far to be productive as a critical analytical tool. Neo-liberalism suffers from promiscuity (hanging out with various theoretical perspectives), omnipresence (treated as a universal or global phenomenon), and omnipotence (identified as the cause of a wide variety of social, political and economic changes). Alternative ways of treating neo-liberalism as more contingent and contested are considered. These emphasize its mobile and flexible character, stressing processes of contextual assemblage, articulation, and translation. The article concludes by wondering whether the concept of neo-liberalism is now so overused that it should be retired.
\end{abstract}

Keywords: assemblage, articulation, authority, globalization, neo-liberalism

Neoliberalism seems to be everywhere.

-Jamie Peck and Adam Tickell

Neoliberalism seems to mean many different things depending on one's vantage point.

- Aihwa Ong

This article starts from the puzzles identified by these quotations. They point to what I think of as the core problems of neo-liberalism as a concept: it is omnipresent and it is promiscuous. There may be a third: that neo-liberalism is omnipotent, but we will come to questions of power later. I am intrigued by the two quotations in part because of what work the word "seems" to be doing in each of them. It opens up a moment of critical distance. For Peck and Tickell (2002), the critical distance concerns precisely how to think of the relationship between neo-liberalism and space. For Ong (2006), it creates the condition for critical reflection on how to think-or rethink-neoliberalism as an analytic category. In the course of the article, I will take up these as central issues for considering the "translation" of neo-liberalism. But first, let me offer a word of warning about the article. It is deliberately conversational in approach. It forms part of a long-running conversation centered on the question of neo-liberalism. This is sometimes a 
conversation with myself, sometimes with friends, and sometimes with people with whom I feel less comfortable. It represents one more attempt to wrestle with puzzles that continue to trouble me in analytical and political ways (e.g., Clarke 1991, 2004a, 2004b).

\section{Promiscuous neo-liberalism}

The question of what we might mean by neoliberalism is a difficult one. The answers to this question are various, divergent, and overlapping. The simplest answer is, perhaps, David Harvey's view of neo-liberalism as the political/ideological project of a class seeking to change the balance of power in global capitalism and create new means of capital accumulation (Harvey 2005). The attraction of this answer is that it is simple, it is evident everywhere, and applies to a variety of economic and social phenomena, from extensive land dispossession through to the new flexibilities of capital or to the dismantling of the social state (in societies of the North/West).

A related answer would perhaps stress the political-ideological dimensions more emphatically, pointing to the dismantling of earlier political settlements and their forms of institutionalization (welfare states, forms of citizenship, corporatist settlements between capital and labor, Atlantic Fordism, etc.). These changes create new ways of thinking, new political formations, and new institutional forms that can be characterized as neo-liberal because they involve both the direct expansion of the scope and reach of corporate capital, and the indirect "economization" of areas of social and political life (public functions to be either privatized or "run like a business," for example). This view would focus rather more attention on the political and ideological levels of analysis, and would be especially concerned with processes of state reform or transformation, and about the spatial and scalar restructurings with which it is associated (e.g., Hartmann 2005; Jessop 2002; Peck 2004).

Despite their different emphases, these two views are linked by a foundation in political economy, whether addressing forms of capital accu- mulation directly or being more connected to what Jessop might call their "societalization" in different regimes that attempt to organize and reorganize time and space. It is this analytic focus that marks their difference from a set of approaches to neo-liberalism that views the concept through a Foucauldian analytic of governmentality. Here neo-liberalism marks the rise of technologies of governing populations that construct "economic" logics of calculation and invite people to become "self-governing" (e.g., Ong 2006; Rose 1999). Such conceptions of neoliberalism as governmentality link sites and technologies as diverse as the management of security or the constitution/regulation of a global space, the rise of NGOs (non-governmental organizations) as a mode of governance in and of civil society, through the economization of the calculating self (as entrepreneur, as consumer, as prudential risk taker, etc.), to the rise of therapeutic technologies of the self. ${ }^{1}$

Although I have sketched these as three different answers (see also Barnett 2005; Larner 2000), the boundaries between them blur and are traversed, as is usually the case with boundaries. From all three perspectives, some of the same trends or tendencies are visible, even if they are made to mean slightly different things. For example, the much-cited renaming of an unemployed person claiming unemployment benefit as a "job seeker" by the UK's Conservative government can be read as (a) evidence of the subordination of social policy to the power of capital and the liberation of the market; (b) evidence of trying to create a new "economized" or "market centric" rhetoric in displacing social democratic, welfarist, or citizen-centered institutions; or (c) an instance of a governmental technology for producing subjects who understand themselves as "entrepreneurial" or "willing selves" (Maasen and Sutter 2007).

It might be that these boundaries are both blurred and traversed by the question of economics. Although the economic is clearly at the centre of political economic analyses of the reformation of capital, it mutates in the second version to include questions of neo-liberalism as “economic discourse" (Peck 2004: 394), whereas 
some Foucauldian work locates the discursive and governmental "economization" of social and political life as a key feature of neo-liberalism (Brown 2005; Rose 1999). There are two points to be made here. On the one hand, these are not exactly the same "economic": one refers to a material substructure of forces, relations, and interests (which may be more or less directly expressed in political and ideological forms); the other refers to a view of the "economic" as those practices, relationships, and forms of organization that are discursively constituted as economic through governmental work. This issue is both a focus of coincidence and analytical frustration. On the other hand, we might take this coincidence not as the effect of bad theoretical work, but as indicating something troubling about both the central and problematic character of "the economic" in contemporary transformations. I realize this is a rather weak formulation-but I am not sure I can reconcile the epistemological, theoretical, and political divergences between Marxism and Foucauldian analysis here (if ever...). They will, however, continue to haunt the concept of neo-liberalism.

\section{Omnipresent neo-liberalism}

"There has everywhere been an emphatic turn towards neo-liberalism in political-economic practices and thinking since the 1970s. Deregulation, privatization and withdrawal of the state from many areas of social provision have been all too common. Almost all states, from those newly minted after the collapse of the Soviet Union to old-style social democracies and welfare states such as New Zealand and Sweden have embraced, sometimes voluntarily and in other instances in response to coercive pressures, some version of neo-liberal theory and adjusted at least some policies and practices accordingly." (Harvey 2005: 3)

I have some trouble with the view that everywhere is neo-liberal even if the local forms vary somewhat. This view risks making neo-liberalism the next-generation "globalization" concept, and we might remember the difficult work that was needed to "unlock" the oppressive and overwhelming weight that the concept of globalization carried-and the sense of inevitability that was associated with it (Massey 2004a; see also Barnett 2005). But if it is not everywhere, is neoliberalism merely the new colonialism, articulating metropolises and peripheries in new forms of ruling at a distance? How to understand the complicated spaces of neo-liberalism has been the subject of much critical discussion in geography that has explored its uneven expansion, its variegated "local forms," and its hybridity. For example, Peck argues that:

"While neoliberalism may have begun life as a North Atlantic intellectual movement, its mutation into a variegated and internationalized state project over the past thirty years has been associated with a profoundly transnational process of 'social learning' which has established new circuits of neoliberal economic and legal expertise, new material connections between financializing and globalizing economies and new forms of connection around neoliberal norms" (2004: 402).

I have argued elsewhere that neo-liberalism is a political-cultural project that aims at transnational hegemony, in which different places are invited, seduced, and compelled to join (Clarke 2004a). Peck points to the strange "doubling" of general and particular in this process: "Each and every neoliberal transition, in this sense, is distinctive though each also remakes the relationship between the part (an actually existing neoliberal case) and the whole (the abstraction that we might provisionally term neoliberalism-ingeneral)" (2004: 395). But this "neoliberalism-ingeneral" is itself a profoundly practical spatial imaginary: each specific neo-liberal transition is (further) evidence of a neo-liberal world, which adds to the isomorphic pressures on other places to "conform."

For me, this also suggests the importance of the different modes of insertion into "global" neo-liberalism that are experienced by different regions, nations, and more local places. It also 
suggests the importance of the transnational relations through which such insertions are conducted. "South East Europe" forms such a "node" where the processes and practices of insertion look complicated, multiple, hesitant, and ambiguous-as are the ways in which they are locally articulated. This brings me to recent arguments by Aihwa Ong discussing how to think about the complicated distribution of neo-liberal governmentality. Ong is concerned with how neoliberalism "is reconfiguring relationships between governing and the governed, power and knowledge, and sovereignty and territoriality" (2006: $3)$. This involves a different view of neo-liberalism's "unevenness." Rather than seeing it as a "tidal wave" that rolls across all places (emanating from the dominant metropoles), Ong treats neo-liberalism's spread by examining it as an assemblage of technologies, techniques, and practices that are appropriated selectively, that come into uncomfortable encounters with "local" politics and cultures, and that are mobile and connective (rather than "global"): "It therefore seems appropriate to study neoliberalism not as a 'culture' or a 'structure' but as mobile calculative techniques of governing that can be decontextualized from their original sources and recontextualized in constellations of mutually constitutive and contingent relations" (2006: 13).

I find Ong's insistence on treating neo-liberalism as a mobile assemblage helpful. The forms, sites, mechanisms, and practices of such mobility are critical-not least for how transnational institutions, practices, agents, and "traveling knowledges" come to work on new sites. Rather than assuming a neo-liberal core or essence that is everywhere the same (and from which divergences might be measured), she captures something of the diversity of specific forms and formations of neo-liberalism. It locates the political and governmental work of neo-liberalism in practices of articulation, dis-articulation, and re-articulation that are, for me, central to processes of rule, domination, and hegemony (Clarke 2004a). In the process, this restores the issue of spaces, sites, forms, and resources of contestation, resistance, and recalcitrance.

\section{Omnipotent neo-liberalism}

There is little in the present for which neo-liberalism cannot be held responsible. As I was preparing this article I encountered the following list of sites, institutions, processes, and practices that were identified as neo-liberal (and I do not think the list is exhaustive):

states, spaces, logics, techniques, technologies, discourses, discursive framework, ideologies, ways of thinking, projects, agendas, programs, governmentality, measures, regimes, development, ethnodevelopment, development imaginaries, global forms of control, social policies, multiculturalism, audit cultures, managerialism, restructuring, reform, privatization, regulatory frameworks, governance, good governance, NGOs, third sector, subjects, subjectivities, individualization, professionalization, normalization, market logics, market forms of calculation, the destatalization of government and the degovernmentalization of the state

That's an impressive list, even for an omnipresent and promiscuous concept. It returns me to a double question, concerning what is, and what is not, neo-liberal. If everything is neo-liberal, then Bondi and Laurie are right that "there is no uncontaminated form of, or space for, political resistance" that can be seen as remaining "wholly outside neo-liberalism" (2005: 399). But we might want to draw a distinction between the presence of neo-liberalism almost everywhere, and whether it is everywhere dominant. All sorts of things-especially discourses or ways of thinking — can be found almost everywhere, but that is not necessarily an index of their power. Rather, we need to ask: Do they form the dominant or organizing principle for the places and sites where they appear? This brings me back to practices of articulation and assemblage.

I want to suggest that adding the adjective "neo-liberal" to a site, process, or practice might conceal two different political relations. The first, most obvious, one is that this site, practice, or process is the effect or consequence of neoliberalism: it would not exist without neo-liber- 
alism. The second meaning identifies the neoliberal articulation of a pre-existing site, process, or practice. Whether we treat neo-liberalism from the standpoint of capitalist regimes of accumulation, or as a version of liberal governmentality, most of its political work involves practices of de- and re-articulation: reorganizing principles, policies, practices, and discourses into new configurations, assemblages, or constellations (Li 2007a). To take a couple of examples, both development as a set of relations and processes centered on power, and managerialism as a way of organizing power in organizations, have longer histories than can be encompassed by neo-liberalism (see e.g., Clarke and Newman 1993; Kothari 2005; Pollitt 1993; Sharma forthcoming). So how does neo-liberalism rearticulate them into new formations? Articulation here might be understood as referring to their "internal" composition (innovative ways of thinking and doing, with new ways of ordering, legitimating, and exercising power) and their "external" configuration with other institutions, policies, and politics. I think this view of the "neo-liberalization of things" is more useful, not least because this conception of articulated formations (internal and external) enables an understanding of why they might be sites of contradiction, strain, antagonism, and ambivalence.

\section{Neo-liberal cohabitation}

By cohabitation I mean to identify the problem of how neo-liberalism lives with "others" in the world. As a political-cultural project it must find ways of engaging with other projects, seeking to displace, subordinate, or appropriate them. Most attention has been focused on the work of displacement-the exclusion, marginalization, or residualization of other projects, discourses, and ways of imagining the world and life within it. There are also the processes of subordination and appropriation. Each of these terms accounts for the continued place of alternative politicalcultural projects in a neo-liberal dominated or directed assemblage. Subordination points to the allocation of secondary or subsidiary roles for other institutions, practices, and discourses: allowed to function but in more confined spaces, with narrowed scope (residual versions of the "social" or "welfarism," perhaps; Clarke, 2007). Appropriation points to a more active process that some have described as cooption or incorporation. For example, Kothari (2005), writing about the politics of development, argues that the neo-liberal agenda "co-opted the 'alternative' critical discourses" of development. As a consequence:

"Forms of alternative development become institutionalized and less distinct from conventional, mainstream development discourse and practice. ... This strategy of appropriation reduced spaces of critique and dissent, since the inclusion and appropriation of ostensibly radical discourses limited the potential for challenge from outside the mainstream to orthodox development planning and practice... .As these approaches were adopted they were embedded within a neoliberal discourse ... and became increasingly technicalised, subject to regimes of professionalisation which institutionalized forms of knowledge, analytical skills, tools, techniques and frameworks." (Kothari 2005: 438-9)

This view of co-optation hints at the discursive and political work of articulation-taking existing discourses, projects, practices, and imaginaries and reworking them within a framing neoliberal conception of development and its place in the world. Just as Kothari points to the incorporation of alternative/critical approaches to development, and work on "difference" points to the reworking of radical politics of difference into a normalized model of the individual consumer citizen (Richardson 2005), so other wouldbe transformative political projects have been appropriated and reworked through a neo-liberal frame. Dagnino (2006), writing about struggles over citizenship in Brazil, points to the "perverse confluence" between key organizing ideas and principles of social movements and neoliberal politics, especially those of "participation" and citizenship, which were centrally articulated by radical movements: 
"There is thus a perverse confluence between, on the one hand, participation as part of a project constructed around the extension of citizenship and the deepening of democracy, and on the other hand, participation associated with the project of a minimal state that requires the shrinking of its social responsibilities and its progressive exemption from the role of guarantor of rights. The perversity of this confluence reflects the fact that, although pointing to opposite and even antagonistic directions, both projects require an active, pro-active civil society...

"A particularly important aspect of the perverse confluence is precisely the notion of citizenship, which is now being redefined through a series of discursive shifts to make it suitable for use by neo-liberal forces. This new redefinition, part of the struggle between different political projects, attests to the symbolic power of citizenship and the mobilizing capacity it has demonstrated in organizing subaltern sectors around democratizing projects. The need to neutralize these features of citizenship, while trying to retain its symbolical power, has made its appropriation by neo-liberal forces necessary" (Dagnino 2006: 158f.; emphasis in original).

Dagnino talks about the political frustration and confusion resulting from the "apparently shared discourse" (2006: 162) in ways that are echoed by Bondi and Laurie's observations about the "sense of uncertainty, ambivalence and perplexity about the politics of the processes we were observing and analyzing" (2005: 394). This "confusion" emerges precisely at the point of appropriation, articulation, and transformation exercised by the neo-liberal re-framing of existing radical, alternative, and contestatory discourses. Neo-liberalism is marked by a capacity to bend these words (and the political and cultural imaginaries they carry) to new purposes.

\section{Looking for the heart of neo-liberalism}

Of course, neo-liberalism is heartless-both metaphorically and analytically. Attempts to define a core or essential neo-liberalism have to struggle with three problems: the variations of neo-liberal discourses, technologies, and interventions; the changing repertoire of neo-liberalism over time; and the effects of strategies of appropriation/articulation. For example, Peck tackles the first of these questions-about how to "chart this fluid, multidimensional and hybridized historical geography" (2004:403). I quote his argument at some length since it poses a set of difficult problems:

"As a composite ideological structure, neoliberalism cannot be reduced to any one of its constituent elements. The state project of neoliberalism was not constructed solely in the global North, nor exclusively in the South, but in both. Neoliberalism is not solely an expression of freemarket libertarianism, nor is it just an outgrowth of neoconservative moral authoritarianism, but it reflects both. Neoliberalism is not only a reactionary response to fiscal and debt crises, nor is it merely a handmaiden of financialization and corporate globalization, but it is both. Neoliberalism-in-general is a loose and contradictionladen ideological framework that is evolving not only through conflict with the 'external' social worlds that it encounters but also through vacillating tensions between its own authoritarian and libertarian moments and constituencies.... So, neoliberalism does not, and cannot, exist in pure form, but only manifests itself in hybrid formations. Even the Bush and Blair projects, located as they are within the neoliberal 'heartland,' are appropriately characterized as hybrids, and as such they are no 'less hybrid' than the neoliberalizing regimes of Chile or Mexico. Yet the fact that a range of critical analysts, many of them working within different theoretical and political traditions, continue to draw attention to the shared neoliberal features of these hybrids points to the importance of developing adequate accounts of neoliberalism-in-general, without succumbing to the fallacies of monolithism, functionalism or convergence thinking. However, the observation of family resemblance presupposes the existence of a (neoliberal) family; the naming of hybrids presupposes a more than trivial degree of neoliberal content. In the absence 
of a more careful mapping of these hybrids-inconnection, the concept of neoliberalism remains seriously underspecified, little more in some cases than a radical-theoretical slogan" (Peck 2004: 403).

There is much here to reflect on (without even engaging with the problems of biological-genetic conceptions of families and resemblances). But we may want to take up the concern with internal contradictions, the hybridizing effect of external encounters, and the problem of identifying a core for a composite ideological structure. These problems are exacerbated by the relationship between spatial differences and temporal differences in neo-liberalism's career. In transnational relations, for example, each specific local/national instance of neoliberalism in practice is going to be located in relation to "previously existing neoliberalisms" in other places and other institutions. Equally, Ong stresses the innovative character of neoliberalism (e.g., as innovative spatial administration; 2006: 19) and notes that the practice of articulation itself inserts a specific temporal dimension to neoliberal governmentality (Ong 2006: 17). As a result, neoliberalism cannot be seen as having a static core since it is consistently drawn into new entanglements as it tries to colonize the world.

But what might give these different appropriations their neo-liberal character or form? I want to suggest that the coherence is provided by the combination of a logic of market rationality, a conception of personhood (centered on, but not exclusive to, human individuals), a calculating framework of efficiency, and a view of authority as a fundamental political and social bond. Each of these brings a distinctive inflection to thinking about the ordering and governing of societies. The market logic seeks to establish universalizing principles of ordering human affairs (through market relations, or, if necessary, through market-mimicking processes: see many of the reforms of public services under the New Public Management, for example). The second works on a model of the self-possessed and selfpossessing independent individual, borrowed from the white adult male figure so central to the original formations of liberalism (or "possessive individualism" to use Macpherson's [1962] phrase). But this is now extended to the incorporation of previously excluded categories of individuals (previously understood as possessed by others, or by forces, drives, passions, or even traditions beyond their control). But this conception of personhood is also extended to other entities—corporations, enterprises, and even markets-as agentic beings. This idea of personhood allows for boundaries to be drawn (as it did in earlier liberalisms). At least three categories of person are visible in contemporary governmental discourse: established "independent" persons, people who might be "empowered" to become independent (through techniques of self-development), and the "residue" requiring containment and control. Third, the calculating framework of efficiency is linked to, but not the same as, market logic. It establishes norms and ways of calculating value. These are typically "economic," and often expressed in fiscal calculations. But they are also linked to questions of personhood in terms of evaluating "subjects of value" (Smith 1997) as "hard working" producers, "responsible" consumers, "effective" parents, and so on. Finally, the question of authority is central to the lexicon of neoliberalism (and is one critical site for its articulation with other political projects, not least conservatism and neo-conservatism). Forms of authority are multiple-the authority of the market, of the consumer, of the family/household, of corporations (and the "business community"). Much has been made of the shift to "private authority" (Slaughter 2004), but it may be more important to explore the blurring, interweaving, and fusing of different forms and sites of authority in neo-liberal political and governmental projects.

I realize there is nothing particularly new about these four elements, nor are they individually unique to neo-liberal ways of thinking and doing. It is their combination and interplay that marks the distinctiveness of neo-liberalism, and it is their co-existence that enables neoliberalism's flexibility in processes of appropriation/articulation. Each can operate as a point of 
articulation with other projects and discourses, and not all need to be in play in that process. The elements have to be coherent, but that does not mean an absence of contradictions (which may explain why so many neo-liberal political projects in specific national settings manage to be liberal and authoritarian?). This view of a core of elements borrows in part from Catherine Kingfisher's distinction between what she calls the "preliminary grammar" of neo-liberalism and its "disjointed, disjunctured articulations" in particular places (2002: 50). She argues that "It is, in fact, only in the circulation of neoliberal related meanings and their articulation with other meaning systems that neoliberalism takes on its multiple and contradictory lives" (Kingfisher 2002: 12).

This points to the capacity of neo-liberalism to circulate: to be decontextualised and recontextualised. It travels well, in part, because it is heteroglossic and multiple. It always has something to offer and that something promises to be universal, modern, and efficient. It has also been successful at colonizing the transnational networks of transmission and translation. Neoliberalism expresses the conditions of its own flexibility and mobility. Ong argues that "Neoliberalism can also be conceptualized as a new relationship between government and knowledge through which governing activities are recast as nonpolitical and nonideological problems that need technical solutions" (2006: 3).

Here I want to argue that neo-liberalism should be understood as the latest in a dishonorable history of strategies of "depoliticization" of politics that attempt to conceal the problems and conflicts of politics behind an appeal to forms of knowledge and varieties of technical expertise (see e.g., Ferguson 1990; Rancière 2006). Perhaps the most interesting thing about this history is the vulnerability of such depoliticizing strategies to challenge and contestation. None of the ones that I know look like permanently stabilized successes. De-politicization carries with it the possibility, and indeed threat, of re-politicization. Such strategies usually involve fairly anxious work devoted to maintaining their non-political and non-ideological claims, pro- tecting the forms of knowledge and power from contesting incursions, or merely from the skeptical gaze of doubtful publics (Clarke 2005).

However, this view of neo-liberal governmentality as constructing itself as non-political and non-ideological raises a problem that governmentality analyses have with the question of politics. The emphasis on the field of the governmental deliberately displaces the state as the central focus of analysis, but risks losing something of the political as well as administrative/ governmental formation of states as contradictory and contested formations. At the same time, subjects appear to be locked within the field of governmental subjection-at best engaged in negotiating its complex terrain or folded into ethical or agonistic conflicts that are always already framed by the governmental rationalities in play (see e.g., Ong's earlier (1993) analysis of "cultural citizenship"). I doubt whether the field of government can ever be quite so all-encompassing or coherent. Instead, other rationalities, political imaginaries, and projects occur that overflow the drive to incorporate, subject, and enmesh. These might be residual attachments that cannot be adequately incorporated or displaced, they might be appropriations that come loose from their neo-liberal fixings (articulation always implies the possibility of re-articulation), or they might be emergent projects shaped by forces and imaginings that cannot be contained (Clarke, Newman, and Westmarland 2007). I do not intend to develop this sketch of possibilities here, but it seems to me that thinking about a singular governmentality must always be attentive to potential alternatives (see also Laurie, Andolina, and Radcliffe's [2005] discussion of indigenous knowledge). As Sharma argues in the context of NGO "empowerment programs" for women in India:

"Perhaps a more productive question to ask is what kinds of subjects are being produced by this use of empowerment and the resulting increase in interfaces between subaltern women and state agencies. Do women's 'expanding relationships [to state institutions and processes] produce only active political subjects, or do they 
also produce regulated, subordinated, and disciplined state subjects?' (Brown 1995: 173). My analysis of the MS program substantiates Chatterjee's (2004) claim that governmental programs do not just produce bureaucratized and passive state subjects. In postcolonial contexts, these programs produce active, sometimes dissident, political actors who can provide the ground for mobilizations of political society in which marginalized subjects make claims on the state, negotiate entitlements, and contest social hierarchies (Chatterjee 2004). Governmentalization does not depoliticize so much as it spawns a subaltern politics that may take new, unexpected forms." (2006: 81)

As a result, I want to argue for a rather different view of the conditions of governmental innovation as existing outside of, or beyond, the reach of the governmental. There are conditions, call them problems, crises, issues, that become recognized as needing to be governed, or governed better. This clearly includes the possibility of previous governance failures (Li 2007b). Here we might see neo-liberalism not just as the mutating progeny of earlier liberalisms, but as governmental inventions demanded to address, recognize, name, and manage problematic conditions that appear to be beyond the capacity of earlier modes of governing. ${ }^{2}$

Despite the appeals of political economy, these are never just the problems and antagonisms of capital accumulation. They are about social relations - and the turbulence of the social-in a wider sense. Governmental innovation can be thought of in terms of how to overcome crises, blockages, dislocations, and unruliness that are threats to "optimization." Some of those appear as "economic," or are to be handled through "economic logics"-but they have to be understood as social in the widest sense, and as political when they appear as movements and projects that demand not to be governed in the old way. Such a view of crisis and dislocation might enable us to understand "innovation" better, and might also point to the persistence of contradictions, disorders, and antagonisms (which new governmental interventions may manage to con- tain, rework, or displace, but may not resolve). Governmental interventions may also give rise to new antagonisms, contradictions, and crisespart of the disorderliness of governing (Cooper 1998).

\section{Translating neo-liberalism: Multiple and graduated sovereignties}

For me, one of the most important features of Ong's recent approach to neo-liberalism has been precisely its combination of issues of translation with questions of sovereignty. Translation-like articulation-puts an emphasis on discursive practices in a way that opens up analytical and political possibilities. ${ }^{3}$ Arguing for ethnographic attention to how neo-liberalism is mobile, and how translation into specific contexts works, Ong indicates how working through the concepts of articulation, negotiation, and translation makes possible a more open-ended and differentiated form of analysis:

"[A]rticulations also refer to discursive practices as ongoing negotiations of citizenship in conditions of displacement. Articulation as a conceptual temporality permits the exploration of claims as a contingent emergence within particular assemblages of market rationalities, politics and ethics. The stress on discursive negotiation or translation of contradictory elements within the space of conjuncture sidesteps a predetermined opposition or adversary position among elements but maintains a conceptual openness to unexpected possibilities and resolutions. ... A context specific inquiry allows us to capture how opposing interpretations and claims can and do interrupt, slow down, deflect, and negotiate neoliberal logics and initiatives. The temporality of transmission, translation and negotiation in this fluctuating space is fraught with political complication, contingency and ambiguity." (2006: 17)

In many respects, this seems to connect closely with discussions about the emergent construction of forms of governmentality in the space of 
South East Europe (Deacon and Stubbs 2007) and it may be that Ong is correct in arguing that viewing such dynamics from outside the claustrophobic framing of North/South might make the processes of transmission, translation, and recontextualization more visible (2006: 12). What she develops is an orientation to these questions around sovereignty, arguing that sovereignty is being reconstructed through new spatializing practices that divide up territories in new ways, and govern them through differentiated and differentiating means (see also Ferguson and Gupta, 2002; Sharma and Gupta 2007). These innovations include sharing sovereign power with other authorities (supra-national agencies, multi-lateral agencies and corporations; Ong 2006: 19). This produces a field of graduated and overlapping sovereignties that also differentiate populations and subject them to different types of rule, allocate them to different citizenship statuses, and so on.

These questions of new spatial and scalar organization-and their implication with questions of multiple, graduated, or overlapping sovereignties-seem to me to bear directly on the issues of "making up places." In particular, we can see how both governmental and nongovernmental organizations might be linkedalthough not always in harmonious ways - in the working out of these processes. Such agencies work as practices of transmission and translation-connecting spaces and scales in innovative ways. They also articulate different voices, claims, and forms of authority in representing and regulating new places. Like Sharma, Ong sees NGOs in particular as occupying an ambiguous or ambivalent role in these emergent sovereignties-functioning as both agents of transmission and as agencies of representation and political-ethical claims-making on behalf of marginalized, excluded, and exploited groups (forms of "noncitizenship"). Both analytically and politically, ambivalence seems an appropriate relationship to both states and non-state governing. Located in the processes of managing contradictions and antagonistic social relations, it would be surprising if they were not the site of ambiguity and ambivalence.

\section{Living without neo-liberalism: A thought experiment}

I want to rescue a series of propositions from this ramble around neo-liberalism. These are what I think of as my temporary standpoints for worrying about neo-liberalism. They are temporary, fragile, and vulnerable to collapse. But for the moment they may allow me to put together some almost coherent thoughts. They are linked by a concern with a set of words such as contradictions, construction, and conflict on the one hand, and ambivalence, assemblage, and articulation on the other. ${ }^{4}$

First, it would be a good idea to think of the social field with which neo-liberalism engages as a disorderly one, characterized by contradictions, antagonisms, and contested political projects. Neo-liberalism provides a political and governmental repertoire for trying to intervene in such fields and direct them in particular ways. Second, such political and governmental projects struggle to resolve, reconcile, contain, or displace contradictions and antagonisms (more or less successfully). As innovative strategies they may also generate new contradictions, antagonisms, and dysfunctions. Third, innovative political and governmental strategies have to be developed to manage the contradictions, antagonisms, dysfunctions-and even failures-of neo-liberal projects. Are these also neo-liberal?

Fourth, neo-liberal strategies realign-in contradictory and complex ways-formations of spaces, scales, and sovereignties. Fifth, neoliberalism involves articulating practices-appropriating other discourses, practices, and even imaginaries and inflecting them. It enables us to grasp its flexibility and mobility. Sixth, neoliberalism therefore denotes a double process of articulation and assemblage: first, the articulation of things into neo-liberalism's repertoire; second, the articulation of elements from neoliberalism's repertoire into specific/local assemblages or constellations as part of political and governmental projects to remake particular places. And finally, articulation always implies the possibility of re-articulation - the attachment of words, symbols, practices, policies, and so on 
to alternative voices, vocabularies, imaginaries, and projects.

As usual, I want to emphasize these propositions because they imply a way of thinking about neo-liberalism that reduces its density and totalizing weight — and the analytical and political breathlessness that such weight induces. Keeping neo-liberalism "open" in these ways announces the possibility of thinking about what is not neo-liberal... and thus the possibility of living without neo-liberalism. What concepts would we need to use, or construct, in order to think about the present without using the concept of neo-liberalism? If my description of its omnipresence, omnipotence, and promiscuity is correct, then perhaps we need terms that would allow us to think better. Neo-liberalism-as a concept—feels overworked: a more welfarist or even compassionately conservative regime would retire it. Instead, we keep on finding ways of making it do more work, and saving ourselves the trouble...

\section{Acknowledgments}

This article was originally written for a workshop on "Transnational Governmentality in South East Europe: Translating Neo-liberalism on the Sovereign Frontier-Concepts, Cases, Contestations," held in Rabac, Croatia 1-3 June 2007, funded by the Friedrich Ebert Stiftung and organized by Paul Stubbs. It was written while I was part of a three-month Maison des Sciences de l'Homme Programme International d'Etudes Avancées "Comparing scales of citizenship: between legal and social representations," at Columbia University Institute for Scholars, Reid Hall, Paris. I am deeply grateful to my colleagues in this program-Kathleen Coll, Evelina Dagnino, and Catherine Neveu-for their efforts to help me think better and for tolerating my obsessions. This article also reflects long-running conversations with Clive Barnett, Wendy Brown, Larry Grossberg, Wendy Larner, Janet Newman, and Paul Stubbs. They are, of course, not responsible for its faults (even in an era of responsibilization). Finally, my thoughts have been modified by conversations with colleagues at the workshop and at a subsequent $\mathrm{PhD}$ conference on "Activism and the State of Neoliberalism," held in the Department of Sociology and Social Anthropology at the Central European University in Budapest (22-23 June 2007).

John Clarke is Professor of Social Policy at the Open University, UK. His research and writing focuses on the processes of remaking welfare and states. He is currently working (with Janet Newman) on a book about the conflicts at stake in encounters between changing publics and changing public services.

E-mail: John.clarke@open.ac.uk.

\section{Notes}

1. Two special issues of Antipode devoted to neoliberalism in 2002 and 2005 mark the distance between these two conceptions. The first (34 [3]) deals with neo-liberalism in terms of politicaleconomic restructurings of scale and space. The second (37 [3]) treats neo-liberalism primarily as a set of governmental techniques, technologies, and strategies of subjection in different sites (linked by questions of knowledge and power).

2. This slides past a whole set of problems about the analysis of contradictions, antagonisms, and dysfunctions. But for some suggestive thoughts, see the discussion by Katz (2005) on contradictions between the economic and cultural politics of neo-liberalism, Kalb (2005) on the antagonisms generated by globalization flows, Gough (2002) on the tensions between individualization and socialization in and around neo-liberalism, and Massey (2004b) on the production of the local as a potentially antagonistic field.

3. Translation is growing in significance as a focus of attention (see e.g., Czarniawska and Sevón, 2005; Djelic and Sahlin-Andersson, 2006; Lendvai and Stubbs 2006; Morris, 2006).

4. Because I think in alliterative threesomes, I could also offer uneven, unfinished, and unstable (as descriptions of political and governmental projects); and transnational, translation, and trajectories (as ways of marking the dynamics of changing formations). 


\section{References}

Allen, John. 2003. Lost geographies of power. Oxford: Blackwell Publishing.

Barnett, Clive. 2005. The consolations of 'neoliberalism. Geoforum 36: 7-12.

Bondi, Liz, and Nina Laurie. 2005. Introduction: Working the spaces of neoliberalism. Antipode 37 (3): 394-401.

Brenner, Neil. 2004. New state spaces. Oxford: Oxford University Press.

Brown, Wendy. 1995. States of injury: Power and freedom in late modernity. Princeton, NJ: Princeton University Press.

- 2005. Edgework: Critical essays on knowledge and politics. Princeton, NJ: Princeton University Press.

Chatterjee, Partha. 2004. The politics of the governed. New York: Columbia University Press.

Clarke, John. 1991. New Times and Old Enemies: Essays on Cultural Studies and America. London: HarperCollins.

- 2004a. Changing welfare, changing states: New directions in social policy. London: Sage.

- 2004b. Dissolving the public realm: The logics and limits of neo-liberalism. Journal of Social Policy 33 (1): 27-48.

- 2005. Performing for the public: Doubt, desire, and the evaluation of public services. In The values of bureaucracy, ed. Paul Du Gay, 211-32. Oxford: Oxford University Press, -2007. Subordinating the social? Neo-liberalism and the remaking of welfare capitalism. Cultural Studies, 21 (6): 974-87.

Clarke, John, and Janet Newman. 1993. The right to manage: A second managerial revolution? Cultural Studies 21(3): 427-41.

- 1997. The managerial state: Power, politics and ideology in the remaking of social welfare. London: Sage.

Clarke, John, Janet Newman, and Louise Westmarland. 2007. Creating citizen-consumers? Public service reform and (un)willing selves. In On willing selves: Neoliberal politics vis-á-vis the neuroscientific challenge, ed. Sabine Maasen and Barbara Sutter, 125-45. Basingstoke, UK: Palgrave Macmillan.

Cooper, Davina. 1998. Governing out of order. London: Rivers Oram Press.

Czarniawska, Barbara, and Guje Sevón, eds. 2005. Global ideas: How ideas, objects and practices travel in the global economy. Copenhagen: Liber and Copenhagen Business School Press.

Dagnino, Evelina. 2006. "We all have rights but..." Contesting concepts of citizenship in Brazil. In Inclusive citizenship: Meanings and expressions, ed. Naila Kabeer, 149-63. London: Zed Books.

Deacon, Bob, and Paul Stubbs. 2007. Transnationalism and the making of social policy in South East Europe. In Social policy and international interventions in South East Europe, ed. Bob Deacon and Paul Stubbs, 1-21. Cheltenham, UK: Edward Elgar Publishing.

Djelic, Marie-Laure, and Kerstin Sahlin-Andersson, eds. 2006. Transnational governance: Institutional dynamics of regulation. Cambridge: Cambridge University Press.

Ferguson, James. 1990. The anti-politics machine. Cambridge: Cambridge University Press.

- 2004. Power topographies. In A companion to the anthropology of politics, ed. David Nugent and Joan Vincent, 383-99, Oxford: Blackwell Publishing.

Ferguson, James, and Akhil Gupta. (2002) Spatializing states: Towards an ethnography of neoliberal governmentality. American Ethnologist, 29 (4): 981-1002.

Gough, Jamie. 2002. Neoliberalism and socialisation in the contemporary city: Opposites, complements and instabilities. Antipode 34 (3): 405-26.

Hartmann, Yvonne. 2005. In bed with the enemy: Some ideas on the connections between neoliberalism and the welfare state. Current Sociology 53 (1): 57-73.

Harvey, David. 2005. A brief history of neoliberalism. Oxford: Oxford University Press.

Jessop, Bob. 2002. The future of the capitalist state. Cambridge: Polity Press.

Kalb, Don. 2005. From flows to violence: Politics and knowledge in the debates on globalization and empire. Anthropological Theory 5 (2): 176-204.

Katz, Cindi. 2005. Partners in crime? Neoliberalism and the production of new political subjectivities. Antipode 37 (3): 623-31.

Kingfisher, Catherine, ed. 2002. Western welfare in decline: Globalization and women's poverty. Philadelphia: University of Pennsylvania Press.

Kothari, Uma. 2005. Authority and expertise: The professionalisation of international development and the ordering of dissent. Antipode 37 (3): 425-46. 
Larner, Wendy. 2000. Neo-liberalism: Policy, ideology, governmentality. Studies in Political Economy 63: 5-25.

Laurie, N., R. Andolina, and S. Radcliffe. 2005. Ethnodevelopment: Social movements, creating experts, and professionalising indigenous knowledge in Ecuador. Antipode 37 (3): 470-96.

Lendvai, Noemi, and Paul Stubbs. 2006. Translation, intermediaries, and welfare reforms in South Eastern Europe. Paper presented at the $4^{\text {th }}$ ESPANET conference, Bremen, September 21-23, 2006.

Li, Tania, 2007a. Practices of assemblage and community forest management. Economy and Society 36 (2): 263-93.

- 2007b. The will to improve. Durham, NC: Duke University Press.

Maasen, Sabine, and Sutter, Barbara. Eds. 2007. On willing selves: Neoliberal politics vis-à-vis the neuroscientific challenge. Basingstoke, UK: Palgrave Macmillan.

Macpherson, C.B. (1962). The political theory of possessive individualism. Oxford: Oxford University Press.

Massey, Doreen. 2004a. For space. London: Sage.

. 2004b. Geographies of responsibility. Geografiska Annaler 86 B (1): 5-18.

Morris, Meaghan. 2006. Identity anecdotes: Translation and media culture. London: Sage.

Ong, Aihwa (1993) Cultural citizenship as subjectmaking: Immigrants negotiate racial and cultural boundaries in the United States. Current Anthropology 37(5): 737-51.

- 2006. Neoliberalism as exception: Mutations in citizenship and sovereignty. Durham, NC:

Duke University Press.
Peck, Jamie. 2004. Geography and public policy: Constructions of neoliberalism. Progress in $\mathrm{Hu}$ man Geography 28 (3): 392-405.

Peck, Jamie, and Adam Tickell. 2002. Neoliberalizing space. Antipode 34 (3): 380-404.

Pollitt, Christopher, 1993. Managerialism and public services. Oxford: Blackwell Publishers.

Rancière, Jacques. (2006) Hatred of democracy. Trans. Steve Corcoran. London: Verso.

Richardson, Diane. 2005. Desiring sameness? The rise of a neoliberal politics of normalisation. Antipode 37 (3): 515-35.

Rose, Nikolas. 1999. Powers of freedom. Cambridge: Polity Press.

Sharma, Aradhana. 2006. Crossbreeding institutions, breeding struggle: Women's empowerment, neoliberal governmentality, and state (re)formation in India. Cultural Anthropology 21 (1): 61-95.

- Forthcoming. Empowerment rules: The cultural logics of state formation, gender and development in postliberalization India. Minneapolis: University of Minnesota Press.

Sharma, Aradhana, and Gupta, Akhil. 2006. Rethinking theories of the state in an age of globalization. In The anthropology of the state: A reader, ed. A. Sharma and A. Gupta1-41. Oxford: Blackwell Publishing.

Slaughter, Anne-Marie. 2004. A new world order. Princeton, NJ: Princeton University Press.

Smith, Paul, 1997. Millenial dreams: Contemporary culture and capital in the North. New York and London: Verso. 